\title{
Seasonal Labour Migration: A Case Study of Leh-Town, Ladakh
}

\author{
Binay Krishna Pal
}

Department of Geography, University of Calcutta, Kolkata, India

Corresponding author: binaygeo@gmail.com

\begin{abstract}
This paper deals with seasonal migration of labour in the high altitude Leh town. Ladakh region has emerged as an attractive spot for investment due to tourism, strategic importance and cultural diversity which subsequently generated employment in the informal sector and seasonal jobs. Low population density but high labour demand in this region has led to the labour in-migration from within the state, other developing Indian states (like Bihar, UP, Odisha, Jharkhand etc.) of India as well as from Nepal. Due to extreme climate, access barrier and high transport cost, labourers are compelled to move there in the 'summer' only, where there are comparatively higher income opportunities. This paper aims to understand the migrant labour dynamics, their negotiations and the policy and actions gaps towards beneficial of the labour rights. This study was conducted with the mixed method approach of social research with the data collection techniques of participant observation, focused group discussion, indepth interview and collection of secondary data from various government offices. Findings reveal the precarious conditions of the seasonal labours in their workplace and staying, violations of labour rights, lack of organisation, local bias towards them.
\end{abstract}

Keywords: Employment, Seasonal migration, Negotiations, Policy gaps, mixed method

One of the highest altitude cold deserts Ladakh is very mesmerising territory of attention not only from the tourists but also from the researchers, policy makers, strategists etc. Leh, geographically located in the top of North Eastern side, latitude and longitude of Leh is $34.10^{\circ} \mathrm{N}, 77.35^{\circ} \mathrm{E}$. With the intrinsic beauty laded up with the threat of extreme climate and dry weather, has created a sparse settlement. Located in the Western part of the Tibetan Ladakh region has a strong likeness with the Tibetans. Buddhist are the dominant cultural group in the region which got a semi-autonomous administration recognising its unique cultural heritage. (Rizvi, J. 1996). With the increasing focus after the Kargil War and conflicts escalating with China, union of India has put immense importance on the Ladakh region. Ladakh including the Kashmir region was made semi-autonomous by the Indian union government. Being an autonomous hill region it enjoys the freedom regarding development projects and making it a favourite tourist destination. Leh, is the district head quarter of Leh district, and according to latest census, its population is 45,671 (Census of India, 2011). From the history of Ladakh, it is found that it is not a homogenous region as many foreign and regional languages like Urdu, Hindi, English, Ladakhi, Tibetan, Kashmiri, Punjabi, Nepali and other mother tongues are there due to presence of visitors and workers. (Bray, 2005). Leh was made capital of Ladakh Kingdom by King Sengge Namgyal in the $17^{\text {th }}$ Century from its previous capital to Shey, $15 \mathrm{~km}$ away (Kimura, 2013). Van Beek and Pirie (2008) has also stated that the single culture, economy, ecology and political system doesn't exist so far which was the distinct character in the past. The region can be accessed by roadway only for five months (May to September) due to extreme cold temperature and snowfall.

Development differentials has been the responsible factors behind the migration of labours led by income and employment. It is estimated that one third of Indians are migrants since their birth. It is seen for the last two decades; the mobility of the population has been increased. It is the dominant 
pattern of migration among the poorer group of people who are mobile or temporary staying in a place or circulating over a period. There are no official records of internal migration of people in India, although an informal estimate say 30 million people are migrants, which is 10 million higher from the estimate of Deshingkar in 2005. The dominant receiving areas of migration are agriculturally backward, small towns and industrial areas, coastal areas for fishing and salt panning along with the agriculturally developed regions of Punjab and Haryana. (Deshingkar, 2015). Although the internal migration in terms of the last residence of the people is very low. It means the large number of people are repeatedly migrating to the different parts of the country. In the year 2011 around 3.6\% people are internal migrant whereas the rate was $4 \%$ in the year 2001 (Mistri, 2015).

The major group of the people who migrate are mainly the landless, socially weaker sections specially the schedule castes and scheduled tribes. Small man-land-ratio is one of the major factors towards seasonal migration (Rao, 1986). Migration occur not only as individual decision but also as household decisions where various kinds of market failures like floods, droughts, drop of prices led to insecurity and as there is lack of insurance towards their lives people have to migrate., It does not only occur to maximise the income of the labourers but also to minimise the risk and termed it is as "the new economy" (Stark, O. \& Bloom, D.E. 1985). The family has a key role to play in the destination of migration. Sometimes seasonal labourers are "compensating mechanism used by disadvantageous households" (Haberfeldi et al. 1999) to sustain the family by the choice of migration elsewhere. The various barrier to migration includes, "first, there is risk of open unemployment in moving out of agriculture... The second reason is the cost of travel ... Third, there is a cost of information" (Acharya, 1989). Bourdieu has tried to popularise the idea of habitus, which is "structured and structuring" both, or "structuring" in Farmer's own words (Galtung, 2004). It doesn't ignore the role of human agency created by the migrants, emphasise the pre-existing social inequality inherent in the system which promotes vulnerability and life risk among them. The migration decisions taken by wage labourers are influenced by the earning in comparison to the income from their marginal product from the rural sector. According to a report published by Economic Times, Bihar is the $5^{\text {th }}$ economic state in terms of inward remittance sent through India Post Money Transfer. (Economic Times, 2013). Bartman (2013) in 'Happiness and 'economic migration', argued that happiness does not come on the people due to migration led better income. From the findings from happiness studies, he refers that as long as the minimum threshold is attained by the groups of migrants, increasing income doesn't fulfil to be a parameter to greater happiness.

Labour market is highly influenced by the social interaction of various individuals depending on some common features like place of origin, age group, linguistic, cultural and social background, and their implication resulted into the migration behaviour among the labourers. (Granovetter, 2005; Mitra, 2010; Wahba \& Zenou, 2005; Zhang \& Xie, 2013; Zhou \& Logan 1989; Sharma \& Das, 2017). The Ladakh region is very complex as various modalities affect the lives of the people there. From the various news sources the precarious conditions of the labour have been highlighted as how they survive in extremely cold temperature, lack of basic utensils to normal life support including the availability of oxygen in the air. Demenge et al. (2009) highlighted the role of 'structural violence' in the lives of migrant labour, where the author identified the precarious conditions of the immigrants who come here for road network development. As per the informal discussions with the residents of Leh, the number of migrant labourers who died in 2012 Leh flash flood is still not actually counted. In a case study of a Nepali migrant, Thinle Sherpa, the author has explored multiple dimensions of life cost and violence from many sector to sustain his life. He stated the life of the migrants as in the shade of mountain range of Himalaya which is not usually visualised. Galtung differentiated structural violence from personal violence as it's an act, coming by noone rather it's "built into structure" (Galtung, 1969).

Ladakh has immense importance in the Indian foreign policy due to its strategic location in between Pakistan and China Border. Increased strategic actions and tourism development pushed a lot of development activities through overall infrastructural development by roads and other transport means, development of agriculture in limited territory and scope, growth of small industries, constructions of buildings for housing 
and hotels and commercial purposes. All these activities have led Ladakh region to emerge as an attractive investment destination which subsequently generated employment in the informal sector and seasonal jobs. Low population density but high labour demand in this region has led to the labour migration from the other developing states (like Bihar, UP, Odisa, Jharkhand etc.) of India. In terms of per capita income these states positioned below the national average. Thus, Ladakh region is a realm of diverse migrants group characterised by their different cultural habits and practices. Due to extreme climate, inaccessibility and high transportation cost labourers are compelled to move there during the 'summer' (i.e. From May to September) where there are comparatively higher temperatures. Hence tourists along with the labourers are allowed to enter and work only this duration. Lack of information regarding labours is one of the major problems of research in temporal dynamics of labour migration. Internal seasonal migration is always stressful to the migrants as there are least records towards the mobility of the people. In the above context, this paper aims to bring out a) factors and process of seasonal inter-state migration of labours; b) The negotiations of migrants in outside environments; c) Policy and implementation gaps in the protections of labours rights/ demands. Keeping all the above context Leh town of Ladakh region was taken as the geographical unit of this study.

\section{MATERIALS AND METHODS}

This study was conducted with the approach of mixed method of social research which includes the quantitative and qualitative both. Available secondary data were referred after the field observation from various sources like books, published journal articles (both printed and online). Influenced by the method of grounded theory (where it emphasises to make a detail ground analysis without influence of previous theoretical propositions) the focus was to collect as much as relevant information and facts from the field with the tool of inductive method. However, it was latter articulated with the findings from the other scholars', worked on the labour issues elsewhere. Total number of respondents have been taken 62 migrant labourers belonging to the states of Bihar,
UP, Jharkhand, West Bengal etc. keeping in mind the further scope of study of the said group. Following the principle of qualitative data collection, saturation of findings has been taken as a parameter for upper limit of selection of samples. Data was collected in the summer of 2017 during August to September. Basic statistical techniques like mean, median and standard deviation were used to extract the central tendency of income and disparity. Majority of the respondent migrants are belonging to the age group of $20-45(83 \%)$ while rest of the people $(17 \%)$ are more than 45 years but not more than 54 years. All the people surveyed are male and have educational qualification ranging between primary to secondary level. Qualitative data collected through in-depth interview with semi-structured questionnaire schedule, four focused group (two in each place) discussions were conducted comprising 8-12 people in each group. Institutional survey was conducted in some office places includes the office of the labour commissioners, Police Stations (SHO \& two local police posts), District Collector's Office, the office of district Statistics Department etc.

\section{RESULTS AND DISCUSSION}

Entire Ladakh region is characterised by the labour migration from different parts of North and East India as well as Nepal. Although the migrants labour work in the other parts of the district and region are different from Leh because of its agricultural and tourism potentiality. There are no specific official records about how many labourers come to stay and work in this region. Head Police Station (SHO), Leh maintain a paper record that how many people are coming from different parts of country and outside country and taking room rent.

\section{Causes of Labour Migration}

Marginal Income in the rural sector: Lower income in highly dense populated regions of Bihar, Uttar Pradesh, Odisa, West Bengal push people to earn better wages where there is labour demand and higher wages. The mean income in home states id about 200 rupees per day per person whereas they earn average 700 rupees per person per day in Leh.

$\square$ Family decisions: Large families is one of the major reason behind the migration of the people as dependency is high due to disguised 
unemployment provides small earning and low family standard due to distributing nominal income.

Weather and Climate: Weather is one of the determining factor of migration both for the place of origin and destination. Respondents told as the summer starts in the month of May they prepare to migrate to cope with the comfortable weather in comparatively lower temperature. These months are also characterised by heavy rainfall led by mosquitos which creates many tropical diseases like Cholera, Dengue etc. Thus migration is not only an economic compulsion but a passage to live in a favourable environment.

Transport and Transport Cost: Due to inaccessible terrain transport is one of the major determinants of migration. Labourers from Jammu and Kashmir although less emphasised due to single mode destination, it's very important for the outsiders as they have to travel through Air Plane, Train as well as Busses. Hence they choice their date of travel on available tickets as well as cheaper the cost (Fig. 1).

Social Network: Labour migration is also influenced by whether the other people are also from same socio-economic-territorial origin. Thus, acquaintances play a strong role in diasporic kinship where any risk is averted by fellow workers. In Leh, it was observed that two group of labour assemble in two different places as well as they also stay in same two ethnic territories.

From the all respondents following factors (for data see Table 1) can be attributed to define in-migration in Leh:

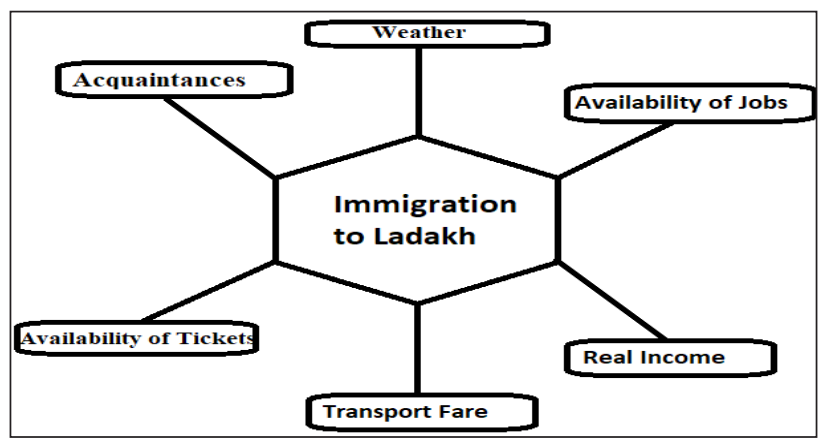

Fig 1: Factors of labour migration in Leh (Prepared by Author from field survey)
The major feature of labour market in Leh is open market labour. Where labourers belonging to two different groups assemble at two different places, viz. Balkhant Chawlk and Polo ground. Where the Balkhand Chalk is for Local labour of Doda District of Jammu \& Kashmir and Polo Ground is for the Outside labour, of Bihar, Odisa, uttar Pradesh etc. The labours outside of Jammu and Kashmir are specialised in some activities like Plastering is done by Jharkhand labourers, Plumbers are mainly from Odisa, Painter are from Bihar and Carpenter are from Punjab. In Balkhant Chawlk around 600-700 labour assemble where around 200-250 return to home due to non-availability of jobs per day. The wage varies from 700-800 daily. These labours are specialised in digging, transfer of goods and materials etc. In Polo ground around 1200-1500 labour assemble there, where 300-500 people don't get jobs and have to return their staying place. Sometimes contractors recruit a group of people for few days. Survey says the violations of paying up wages and harassment happen sometimes. The violation of wage may sometimes come from directly employer's side. However, labourers alleged they are deprived of their wage mostly through the jobs they got by contractors or middleman. Lack of labour union push the labours towards vulnerability as there is no negotiators towards the protections of labour right. Although contractors allege sometimes labourers don't work properly in routine hours which led to non-payment of wage from the employer. Outside labourers responded over protection of rights in the labour commissioner's office towards bias to the local (Toda district) labours.

It is found that the income of migrant labour is $50 \%-70 \%$ higher than that of the people who are not migrating. Although there was no survey conducted on the non-migrants residing their original place, rather it was asked to the migrants what would be the expected income if they don't migrate. In both the labour groups they expressed that they can averagely send 10000 rupees per month for remittances to their home (Table 3), which is higher that they could earn living in their villages. There are inter and intra group wage disparity among the groups. Although the disparity is higher among the outsiders where their standard deviation value (1408.14) is higher than the native labourers (1332.18). 
Table 1: Factors of Labour In-migration in Leh

\begin{tabular}{ccccccc}
\hline Factors of Migration & $\begin{array}{c}\text { Number of Respondents } \\
\text { (Exclusive category, Out of 62) }\end{array}$ & \% to total & $\begin{array}{c}\text { Within State } \\
\text { Migrants }\end{array}$ & $\begin{array}{c}\text { \% to } \\
\text { Total }\end{array}$ & $\begin{array}{c}\text { Outside } \\
\text { Migrants }\end{array}$ & \% to Total \\
\hline Weather & 62 & 100 & 30 & 48.39 & 32 & 51.61 \\
Actual Income & 57 & 91.93 & 22 & 35.48 & 35 & 56.45 \\
Availability of Jobs & 50 & 80.64 & 24 & 38.71 & 26 & 41.93 \\
Air-fare & 43 & 69.35 & 12 & 19.35 & 31 & 52 \\
Availability of Tickets & 42 & 67.74 & 0 & 0 & 42 & 67.74 \\
Acquaintances & 40 & 64.5 & 18 & 29.03 & 22 & 35.48 \\
\hline
\end{tabular}

Source: Primary Survey by the Author (September, 2017).

Table 2: In-Migrants Stayed in Leh (Including Labour)

\begin{tabular}{cccc}
\hline \multirow{2}{*}{ Year } & \multicolumn{3}{c}{ Labour In-Migrated } \\
\cline { 2 - 4 } 2013 & From Jammu \& Kashmir & $\begin{array}{c}\text { From Other States (Bihar, UP, WB, } \\
\text { Odisa, Jharkhand) }\end{array}$ & From Nepal \\
\cline { 2 - 4 } 2014 & Data Not Found & Data Not Found & $\begin{array}{c}\text { Data Not Found } \\
\text { Data Not Found }\end{array}$ \\
2015 & Data Not Found & Data Not Found & 483 \\
2016 & 784 & 2061 & 272 \\
2017 (upto September) & 390 & 1050 & 284 \\
\hline
\end{tabular}

Source: As Provided by Head Police Station (SHO), Leh, September, 2017.

Table 3: Economic Characteristics of Migrants Labours, Leh

\begin{tabular}{ccc}
\hline Indicators of Labour Wage & Jammu \& Kashmir Labourers & Outside Labourers \\
\hline Daily Income & $700-900$ & $600-800$ \\
Number of Working days in a Month & $20-25$ & $22-25$ \\
Minimum Income/ Month & 15000 & 14700 \\
Mean Income/ Month & 18033.33 & 16918.75 \\
Median Income/ Month & 18300 & 17350 \\
Highest Income/ Month & 21600 & 20000 \\
Standard Deviation & 1332.18 & 1408.14 \\
Average Cost of Living/ Month & 5000 & 5500 \\
Remittances/ Month & $10000-12000$ & $9000-11000$ \\
\hline
\end{tabular}

Source: Primary Survey by the Author (September, 2017).

\section{Labour Rights Issues}

Thus, there is an anchoring of the concept of social protection in human rights, set out in the Universal Declaration of Human Rights (UDHR) and subsequent UN conventions. Articles 22 to 26 of UDHR state the universal rights of each individual to a basic standard of life, to proper working conditions, and to social security and social protection. (UNESCO, 2012). Leh Ladakh has lack of Contingent Social Security (CSS), which refers to socially supported institution arrangements to meet conditions of 'adversity' such as sickness, accidents and old age. There are some specific problems associated with the labour and their well beings as discussed below:

Precarious conditions of the seasonal labours in their workplace and lodging. In a room area measured 12 feet/ 10 feet there are around 8-10 labourers. Usually landlords or room owners allot the ground floor by making shared mess rooms. There is no separate place for cooking and very poor ventilation. As they use kerosene 
Table 4: Labour Dispute cases found in Leh, 2013- Sept, 2017

\begin{tabular}{cccc}
\hline Year & Cases Registered & Cases-solved/ Dissolved & Money Recovered/ Distributed \\
\hline $2013-2014$ & 3 & 2 & 54500 \\
$2014-15$ & Data not found & 24 & 924600 \\
$2016-17$ & 72 & 36 resolved and 35 dissolved & 4997300 \\
$2015-16$ & Data not found & - & - \\
2017-till sept, 5, 2017 & 8 & 7 & $3,33,150$ \\
\hline
\end{tabular}

Source: Office of the Labour Commissioner, Leh.

as fuel to cook over stove the chances of respiratory diseases are very high due to small ventilation, untidy condition of floors etc.

$\square$ Violations of labour rights is another major aspect. As the work done by contract system there is no stipulated time for the labour hours. There are no specific healthcare benefits for those labours. Although for primary and moderate critical health conditions they get a very good treatment from the Leh-Hospital, critical cases have to transfer elsewhere bearing the cost by labourers themselves.

Lack of organisation: As the labourers are in unorganised sector, there is no negotiator as union in favour of their demands and rights. Major demands of the labourers are proper wage, minimum standard of staying and facilities of sufficient water, quick redress of disputes, better and cheaper transportation from Jammu Railways Station.

Local bias: as responded by the labourers, the labourers outside the Kashmir reported that the authorities have a local or Kashmir bias towards solving the disputes between labourers and the employers or the contractors of labourers who works as the middleman.

There is no Labour Organisation or union present for the safeguard of labour. Office of the Labour Commissioner looks after the conflicts arise from labour side. There is no register of how many labour come to attend the work at Leh. Rather the Leh Police Station (SHO) registers migrants from outside as the tenants with the landlords.

The labour commissioner office is one of the important institutions made to safeguard the right deliver justice to the labourers. There are contradictory view regarding the role and responsibilities of the conflicts over labour issue with the employer. Where the labour commissioner claims that almost all the issues are taken into cognizance for the interest of the labourers and all efforts are taken for resolution of the disputes (Table 4), the labourers express their misfortune and poor actions of such institution. Labourers also think that they could get better justice if they belong to Jammu \& Kashmir.

\section{CONCLUSION}

The article tried to address the issue of seasonal labour migration and its factors and the negotiations of the labourers. Major characteristics of migratory labour are the seasonality, variability in numbers and income uncertainty. From the above discussions, it is clear that the economic characteristics are not the sole factors of migration, there are other socio-environmental issues which push them out, particularly acquaintances and social networks of the migratory labourers, transport facilities and weather in association with the family decisions. The lodging and hygiene are major issues which need to address very seriously and urgently. The structural violence, assisted by negligent labour policy, lack of labour rights are crucial issues to be addressed very urgently to sustain labour in-flow as well as continuing prosperity. Despite being in a part of development process, building roads and infrastructure of Ladakh, they are largely away from the histories of Ladakh. Although migration is an inevitable phenomenon, safeguarding the rights and welfare of migrants is to be done by the state, incorporating all the stakeholders in Leh- Ladakh.

\section{ACKNOWLEDGEMENTS}

I acknowledge UGC, for funding my research through the conduction of field survey. I also 
express my gratitude to Dr. Mafizul Haque, Dept. of Geography, University of Calcutta, and Dr. Nandini Ghosh of IDSK for giving their valuable inputs to this paper. I also like to thanks the inhabitants of Leh town, migrant respondents and all the Govt. agencies specially, the Leh Municipality Office, LehLabour Commissioner, Disaster Management Dept., Department of Statistics etc. as they cooperated with the data collection process. I also grateful to Anisha Biswas and Rima Pal, students of Geography at Calcutta University as they have assisted me in the field survey and collected data.

\section{REFERENCES}

Acharya, S. 1989. Agricultural wages in India: A disaggregated analysis, Indian Journal of Agricultural Economics, 44: 121-139.

Beek, M.V. and Pirie, F. (Eds). 2008. Modern Ladakh: Anthropological Perspectives on Continuity and Change. Leiden, Brill, pp. 281-301

Bray, J. 2005. Ladakhi Histories: local and regional perspectives, Select papers presented in $9^{\text {th }}, 10^{\text {th }}$ and $11^{\text {th }}$ IALS Colloquia. Leiden, Brill.

Kimura, M. 2013. Past forward: understanding change in Old Leh Town, Ladakh, North India (Master Thesis), Norwegian University of Life Sciences. Norway, pp. 43-44.

Demenge, J.2009. In the Shadow of Zanskar: The Life of a Nepali Migrant, Ladakh Studies, July, 2009 (IDS, Brighton), pp. 1-11.

Deshingkar, P. 2015. Session 3: Realising the Potential for Poverty Reduction Parallel Group 3A: Topic Paper 2, Internal Migration, Poverty and Development in Asia, Asia 2015 Conference, IDS \& ODI. pp. 2-18.

Farmer, P. 1997. On Suffering and Structural Violence: A View from Below. In: Social suffering. A. Kleinman, V. Das and M. M. Lock. (Eds). University of California Press.

Farmer, P. 2004. An Anthropology of Structural Violence, Current Anthropology, 45(3): 305-325.

Galtung, J. 1969. Violence, Peace, and Peace Research,Journal of Peace Research, 6(3): 167-191.
Granovetter, M. 2005. The Impact of Social Structure On Economic Outcomes, The Journal of Economic Perspectives 19(1): 33-50.

Bartram, D. 2013. Happiness and 'economic migration': A comparison of Eastern European migrants and stayers, Migration Studies 1(2): 156-175.

PTI, 2013. 'Bihar at Fifth Position in Terms of Inward Remittance' In The Economic Times,'https:// economictimes.indiatimes.com/news/economy/finance/ bihar-at-fifth-position-in-terms-of-inward-remittance/ articleshow/19632240.cms; Accessed on $1^{\text {st }}$ March, 2018

Mistri, A. 2015. Estimation of Internal Migration in India, 2011 Census based on Life Table Survival Ratio (LTSR) Method,MPRA Paper 61577. University Library of Munich, Germany, pp. 1-16.

Mitra, A. 2010. Migration, livelihood and well-being: Evidence from Indian city slums, Urban Studies, 47(7): 1372-1390.

Rao, M.S.A. 1986. Some aspects of sociology of migration in India. M. S. A. Rao (ed.), Studies in Migration. Manohar, Delhi, pp. 19-36.

Rizvi, J. 1996. Ladakh: Crossroads of High Asia. Oxford University Press, New Delhi, India, pp. 310.

Sharma, A. and Das, M. 2017. Migrant Networks in the Urban Labour Market: Evidence from India, The Journal of Development Studies, 53(1): 1-19.

Stark, O. and Bloom, D.E. 1985. The New Economics of Labor Migration, American Economic Review, 75(2): 173-178.

UNICEF \& ICSSR. 2012.National Workshop on Migration and Human Development in India, 6-8 December, 2011, UNESCO. Pp. 2-193

Wahba, J. and Zenou, Y. 2005. Density, social networks and job search methods: Theory and application to Egypt, Journal of Development Economics, 78(2): 443-473.

Haberfeld, Y., Menaria, R.K., Sahoo, B.B. and Vyas, R.N. 1999. Seasonal Migration of Rural Labor in India, Population Research and Policy Review, 18: 473-489.

Zhang, C. and Xie, Y. 2013. Place of origin and labour market outcomes among migrant workers in urban China, Urban Studies, 50(14): 3011-3026.

Zhou, M. and Logan, J.R. 1989. Returns on human capital in ethnic enclaves: New York City's Chinatown, American Sociological Review, 54(5): 809-820. 
